\title{
GREEN CONSTITUTION SEBAGAI PENGUATAN NORMA HUKUM LINGKUNGAN DAN PEDOMAN LEGAL DRAFTING PERATURAN DAERAH DALAM RANGKA PRAKTIK-PRAKTIK TATA KELOLA PEMERINTAHAN YANG BAIK DI DAERAH
}

\author{
I Gusti Ayu Ketut Rachmi Handayani
}

\begin{abstract}
The purpose of this study is to formulate legal drafting a model policy formulation Regional Regulation based Green Legislation in order to develop the practices of good governance in the region through strengthening the role of the executive (such as the leading sector of legal department Sector, BLH, Central Java Regional Environment and Parliament through strategies, mechanisms, and empowerment potential, and improving procedures for preparing regulations for environment conservation attention. This study is a juridical non-doctrinal, with a qualitative approach. The method will be used through the stages of: mapping the existing condition into the formulation of legal drafting which has been used, mapping of potential executive (leading sector) and the Parliament, to evaluate regulations that have been generated, identify and evaluate the constraints faced in the policy formulation stage, identify opportunities and strategies and formulate a model formulation that can be developed. The emphasis in the context of formulation of legal drafting by the Government to produce a green-based regulation legislation. The results of research are: First, the preparation of formulations Legal Drafting regulations made by the Government in accordance with Act No. 12 of 2011 and Act No. 32 of 2004, but not all use the Paper of Academic regulation in the formulation so that the Legal Drafting Regional Regulation not meet the criteria of a good legal system. Second, participation has not been effective and not all regulation is preceded Academic Paper. Third, the constraints in the formulation of legal drafting regulations include limitations of the preparation of draft environmental preservation, the ability to assess the regulation, the ability to formulate an explicit policy, concrete, clear and operational.
\end{abstract}

Kata kunci: Green Constitution, Legal Drafting

\section{A. Pendahuluan}

Ketika isu lingkungan hidup menjadi perhatian penting bagi kelangsungan hidup manusia istilah green dijadikan simbol atas keprihatinan tersebut. Istilah green economy, green paper, green politic,

Yustisia Vol.1 No.1 Januari - April 2012 green party, green market, green festival dan green building, green office, green campus adalah beberapa istilah yang sudah mulai terdengar. Dalam perjalanan waktu, terlihat adanya peningkatan tekanan-tekanan yang dilakukan manusia terhadap lingkungan hidup. 
Sifat keanekaragaman alam itu sendiri terganggu sehingga terjadi sifat yang monoton, kaku, dan tercemar. Kerusakan lingkungan hidup disebabkan karena dua hal, yaitu karena manusia mengeksploitasi lingkungan hidupnya dan yang kedua karena faktor alam. Dalam posisinya sebagai pendukung, maka lingkungan sebagai ruang bagi manusia dapat mengalami kejenuhan, sehingga tidak dapat lagi memberi dukungan terhadap pertumbuhan suatu populasi. Keadaan seperti inilah yang disebut sebagai batas daya dukung lingkungan. Dengan akal budinya manusia menjadi pusat keberadaan mahluk yang lain. Hal ini disebabkan karena manusia mampu menyadari perkembangan lingkungan di sekitarnya bahkan mampu memanfaatkan lingkungan fisik dan biotik di sekelilingnya, demi perkembangan diri pribadinya. Dalam posisi seperti ini maka keadaan alamiah yang menimbulkan keserasian itu sudah berubah sesuai dengan kemauan manusia yang telah mengadakan campur tangan. Pada kenyataannya akibat dari campur tangan manusia ini tidak selalu membuahkan kemantapan dan kelestarian bahkan sering terjadi kelestarian, keseimbangan dan kemantapan itu goncang dan terganggu oleh ulah manusia (Brown, 1994: 47). Sebagai subyek lingkungan hidup, manusia mempunyai kewajiban etik untuk menjaga agar lingkungan hidup terus berlangsung secara seimbang, sehingga seluruh komponen lingkungan hidup berada dalam suasana yang serasi. Dari segi

Yustisia Vol.1 No.1 Januari - April 2012 spiritual hidup manusia adalah merupakan anugrah sekaligus merupakan atau menyandang tugas (Abdurrahman, 1990: 54). Sebagai sesama subyek pengelola lingkungan hidup, seharusnya antara manusia satu dengan manusia lainnya saling menjalin kerjasama yang serasi dalam memanfaatkan lingkungan hidup guna pengembangan diri dan sesama, menuju pada keadaan yang lebih baik dan bermakna. Keadaan ini dapat tercapai karena dengan kerjasama maka antara manusia yang satu dengan manusia yang lain dapat saling mengisi dan menutupi kekurangan serta dapat saling memberi apa yang diperlukan. Apabila antara manusia yang satu dengan manusia yang lain saling memperbudak atau memperalat untuk kepentingan sendiri maka tujuan pelestarian lingkungan hidup niscaya tidak akan tercapai (Bartleet, 1993: 114). Dalam hidup bersama atau sendiri-sendiri manusia mempunyai kewajiban untuk mengelola lingkungan hidup sehingga mendapatkan hasil atau kemudahan-kemudahan sebagai sarana untuk mengembangkan dan meyempurnakan diri sendiri dan sesama. Karena itu maka pemanfaatan lingkungan hidup oleh seseorang atau sekelompok orang tidak boleh merugikan orang lain atau kelompok lain (Bhatt, 1990: 49). Kelestarian dan keserasian lingkungan sebagai hasil dari pengelolaan lingkungan hidup bukanlah milik perorangan atau kelompok tetapi merupakan milik umat manusia seluruhnya. Untuk mewujudkan hal itu maka manfaat penataan lingkungan bukan hanya untuk dirasakan oleh generasi

Green Constitution Sebagai... 131 
sekarang saja tetapi juga harus dapat dirasakan oleh generasi yang akan datang, sesuai dengan kata-kata bijak "alam lingkungan bukan merupakan warisan nenek moyang, melainkan merupakan hutang pada anak cucu" (Emil Salim, 1991: 37). Manusia dan alam dalam hubungan satu dengan yang lain terkait pada sejarah. Di dalam permasalahan lingkungan, manusia akhirnya berhadapan dengan dirinya sendiri. Dalam alam yang dipengaruhi manusia, manusia yang dipengaruhi alam menemukan dirinya sendiri. Ini berarti, bahwa dalam hubungannya dengan alam, ia harus memperhitungkan nilai-nilai lain, di samping nilai-nilai teknis dan ekonomis. Ini berarti pula, bahwa ancaman terhadap alam tidak dapat dipertanggungjawabkan kepada pihak lain, akan tetapi pada sikap manusia itu sendiri, baik sebagai diri pribadi secara mandiri, maupun sebagai anggota masyarakat (Leenen, 1971). Uraian di atas menggambarkan betapa besarnya pengaruh manusia terhadap lingkungan hidup, sehingga dengan posisi manusia seperti itu harus sungguh-sungguh diarahkan terhadap kewajiban untuk melestarikan dan menyerasikan lingkungan. Tetapi sebaliknya, ternyata lingkungan hidup juga mempunyai pengaruh terhadap manusia, Karena pada hakekatnya manusia itu adalah bagian dari lingkungan hidup. Mengingat kenyataan itu maka harus diusahakan agar jangan sampai manusia menciptakan suasana buruk terhadap lingkungan hidup yang nantinya akan dirasakan oleh manusia itu sendiri. "Perubahanperubahan yang terjadi di daerah lingkungan hidupnya mau tidak mau akan mempengaruhi eksistensi manusianya, karena manusia akan banyak sekali bergantung pada ekosistemnya. Untuk mewujudkan itu maka sistem bermasyarakat, pendidikan dan pranata hidup yang digariskan sesuai dengan kebijaksanaan yang berlaku sekarang, demikian pula kemanfaatan segala jenis sumber daya yang sekarang ada, serta kebijaksanaan kependudukan yang direncanakan, semua itu hendaknya tetap dapat memelihara kelestarian lingkungan hidup dan peradaban manusia di masa mendatang (Siahaan, 1989: 16).

\section{B. Pembangunan Berkelanjutan} hakekatnya adalah suatu proses perubahan pada lingkungan yang selalu menyebabkan terjadinya peristiwa yaitu perubahan yang mengarah pada segi positif dan segi negatif. segi postif kita sebut sebagai hasil pembangunan sedangkan segi negatip disebut dengan istilah dampak dari pembangunan. Konsep pembangunan di Indonesia dikenal dengan istilah pembangunan yang berkelanjutan (sustainable development), yaitu pembangunan yang dilakukan oleh manusia sehingga dapat digunakan untuk mencukupi kebutuhan sekarang dan untuk masa yang akan datang (generasi mendatang). Pembangunan yang berwawasan lingkungan menurut UU No 32 Tahun 2009 tentang Perlindungan dan Pengelolaan Lingkungan yaitu konsep yang melihat adanya kesejajaran antara pembangunan dan

Green Constitution Sebagai... 132 
perlindungan serta pengelolaan lingkungan hidup, sehingga tidak ada pertentangan antara pengelolaan lingkungan hidup dan pembangunan. Dengan kata lain pembangunan yang dilaksanakan tidak akan menimbulkan kerusakan pada lingkungan. Masalah lingkungan hidup mulai mendapat perhatian pada saat Dewan Ekonomi dan Sosial PBB mengadakan peninjauan terhadap hasil-hasil gerakan "Dasawarsa Pembangunan Dunia ke1 (1960-1970)" guna merumuskan strategi "Dasawarsa Pembangunan Dunia ke-2 (1970-1980)". Pembicaraan tentang masalah lingkungan hidup ini secara khusus diajukan oleh wakil Swedia pada tanggal 28 Mei 1968, disertai saran untuk menjajagi kemungkinan guna menyelenggarakan suatu konferensi internasional mengenai lingkungan hidup manusia. Sidang Umum PBB menerima baik tawaran Pemerintah Swedia untuk menyelenggarakan Konferensi PBB tentang LIngkungan Hidup Manusi di Stockholm pada bulan JUni 1972; dan segera membentuk sebuah panitia persiapan. PAnitia persiapan ini diketuai oleh Maurice F. Strong, wakil dari KAnada, yang telah memberikan kontribusi sangat besar terhadap seluruh persiapan konferensi. Dalam Laporan pada tahun 1971, Panitia Persiapan menyarankan adanya enam mata acara konferensi sebagai mata acara pokok, yaitu:

1. Perencanaan dan pengelolaan pemukiman manusia demi kualitas lingkungan hidup.

Yustisia Vol.1 No.1 Januari - April 2012
2. Segi-segi lingkungan hidup dalam pengelolaan sumber-sumber daya alam.

3. Identifikasi dan pengendalian jenis-jenis pencemaran dan gangguan yang berpengaruh internasional secara luas.

4. Segi-segi pendidikan, penerangan, social, dan kebudayaan dalam masalah-masalah lingkungan hidup.

5. Pembangunan dan lingkungan hidup.

6. Implikasi organisasi secara internasional mengenai tindakantindakan yang diusulkan konferensi.

Masalah-masalah bersama dalam lingkungan dihadapi oleh negara-negara berkembang dan menciptakan dampak seolah-olah ada raksasa yang terjaga dan kini sedang menaruh beban yang teramat berat kepada lingkungan. Pertambahan penduduk yang begitu besar berlangsung di atas persada tanah air Indonesia denagn sementara kondisi fisik alamnya relatif tetap, tidak bertambah luas. Luas areal tanah daratan dan lautan tidaklah bertambah besar, sehingga kepadatan penduduk akan turut memberi tekanan kepada sumbersumber alam dan lingkungan hidup terutama di Pulau Jawa dimana jumlah penduduk per $\mathrm{km}^{2}$ nya terus bertambah.

Konsekuensi-konsekuensi

yang paling mengerikan dari pertumbuhan penduduk yang cepat

Green Constitution Sebagai... 133 
diperkirakan oleh beberapa orang ahli muncul di tempat-tempat di mana ukuran penduduk yang cepat diperkirakan oleh beberapa orang ahli muncul di tempat-tempat di mana ukuran penduduk melampaui daya dukung (carrying capacity) tanah. Perkiraan daya dukung tidak ditegaskan atau diuji secara tepat di dalam literatur tentang konsekuensikonsekuensi jumlah penduduk yang melampaui batas. Tekanan penduduk berkonsekuensi pada meningkatnya permintaan akan tanah pertanian dan pengusahaan hutan yang cenderung tidak mengindahkan kelestarian hutan, dan yang pada gilirannya akan meningkatkan erosi serta keadaan tanah yang bertambah kritis. Pada ruang lingkup yang lebih global WCED mensinyalir adanya "Krisis Tiga Muka Lingkungan Hidup" yang melanda dunia, di mana tiga krisis global itu saling berkaitan, menyatu dan saling mengunci (interlocking) dan yang sekaligus mengandung dan mengundang dampak interaksi antara masalah kependudukan, lingkungan hidup dan pembangunan.

\section{Green Constitution}

Permasalahan lingkungan hidup terus berlangsung meskipun sudah banyak Negara yang membuat Undang-Undang Tentang Lingkungan Hidup termasuk Inodesia. Legalisasi lingkungan hidup dalam bentuk peraturan perundang-undangan dan kebijakan pemerintah dianggap belum cukup untuk menguatkan komitmen Negara dalam mengatasi persoalan lingkungan hidup. Kegagalan ini juga terjadi karena masa jabatan pemerintah yang sangat singkat dan mudahnya dilakukan perubahan

Yustisia Vol.1 No.1 Januari - April 2012 terhadap Undang-Undang dan kebijakan pemerintah lainnya. Sedangkan persoalan lingkungan hidup adalah persoalan yang dampaknya terjadi dalam waktu yang panjang sehingga harus ditanggulangi dengan instrument yang berlaku lama pula. Karena legalisasi lingkungan hidup dianggap tidak cukup, maka perlu ditingkatkan penormaan lingkungan hidup pada level konstitusi Negara. Konstitusionalisasi lingkungan hidup dalam konstitusi suatu Negara dianggap penting bukan saja karena konstitusi tidak mudah dirubah, tapi juga karena konstitusi merupakan supreme law of the land yang menjadi tujuan, pedoman dan alat ukur kehidupan berbangsa dan bernegara. Beberapa Negara sudah melakukan konstitusionalisasi lingkungan hidup, misalkan Portugal (1976), Spanyol (1978), Polandia (1997), Prancis (2006) dan Ekuador (2008). Prancis bahkan merubah Preambule konstitusinya dengan memasukkan Environment Charter of 2004. Sedangkan Ekuador menegaskan di dalam konstitusinya bahwa lingkungan hidup merupakan fundamental rights sendiri yang harus disejajarkan dengan Hak Asasi Manusia.

Konstitusionalisasi

lingkungan hidup dalam konstitusi Indonesia sendiri sudah dilakukan dalam amandemen UUD 1945, namun tidak banyak pihak yang memperhatikan hal ini secara serius. Pasal $28 \mathrm{H}$ ayat (1) dan Pasal 33 ayat (4) UUD 1945 merupakan bukti bahwa konstitusi Indonesia adalah Konstitusi Hijau (Green Constitution). Pasal $28 \mathrm{H}$ ayat (1) UUD 1945 berbunyi: "Setiap orang

Green Constitution Sebagai... 134 
berhak hidup sejahtera lahir dan bathin, bertempat tinggaldan mendapatkan lingkungan hidup yang baik dan sehat serta berhak memperoleh pelayanan kesehatan. Sedangkan Pasal 33 ayat (4) UUD 1945 berbunyi:"Perekonomian nasional diselenggarakan berdasarkan asas demokrasi ekonomi dengan prinsip kebersamaan, efisiensi berkeadilan, berkelanjutan, berwawasan lingkungan, kemandirian, serta dengan menjaga keseimbangan kemajuan dan kesatuan ekonomi nasional (Jimly Asshiddiqie. 2009).

Optimalisasi peran pemerintah dan legislative dalam rangka mengahasilkan peraturan berbasis lingkungan (green legislation) merupakan hal yang mutlak diperlukan dalam rangka percepatan implementasi tata kelola pemerintahan daerah yang baik terlebih dalam membuat kebijakan mengantisipasi dampak pemanasan global (climate change). Esty dan Porter dalam tulisannya di Journal of Environment and Development Economics berpendapat the empirical evidence hence suggests that a country can benefit environmentally not only from economic growth, but equally from developing the rule of law and strengthening its governance structure (2005, 391). Pengusung ide-ide lingkungan hidup harus menghadapi tantangan yang sangat tidak seimbang dari penguasa politik, dari panguasa dunia usaha, dan dari masyarakat sendiri. Kalahnya kepentingan lingkungan hidup dalam peraturan yang tidak seimbang melawan kepentingan-kepentingan lain tersebut terjadi tidak hanya di

Yustisia Vol.1 No.1 Januari - April 2012 forum-forum yang teknis eksekutif, tetapi juga di forum-forum politik, di lingkungan lembaga legislatif. Oleh karena itu, di samping ada undangundang lingkungan hidup yang tentu saja berpihak kepada lingkungan, banyak pula produk undang-undang di bidang-bidang lain yang justru tidak ramah lingkungan. Hal demikian tentu harus diterima sebagai kenyataan yang ada di lingkungan lembaga perwakilan rakyat yang menjadi muara dari semua jenis kepentingan yang hidup dan saling bertarung dalam masyarakat. Hasil penelitian lain Faure and Johnston dengan apa yang disebut "pollution haven" yaitu menguji to what extent differences in environmental regulation are important to firms to such and extent that they would decide to take cost differences into account when making adecision on where to lacate their firm or to relocate (2009).

Berkembangnya tuntutan yang meluas agar kebijakankebijakan resmi negara yang prolingkungan dapat tercermin dalam bentuk perundang-undangan yang mengingat untuk ditaati oleh semua pemangku-kepentingan

(stakeholders). Law enforcement menjadi sangat penting saat ini, seperti dikatakan teinzor (1998) ... If one agrees that varying enforcement styles are also related to cultural differences the shift in the US from traditional command and control to a more flexible system of industry self regulation could therefore be a dangerous journey... Tak terkecuali, Indonesia juga menghadapi tuntutan yang sama, yaitu perlunya disusun suatu kebijakan yang dapat dipaksakan berlakunya dalam bentuk

Green Constitution Sebagai... 135 
undang-undang tersendiri yang mengatur mengenai lingkungan hidup. Secara parsial sudah ada kebijakan yang mengakomodasinya, seperti Kota Surakarta, Kabupaten Sukaharjo, Kabupaten Sragen, Kota Tangerang, Kabupaten Ngawi, Kabupaten Blora yang memiliki Perda Pengendalian Lingkungan Hidup, namun demikian, political will pemerintah baik pusat maupun daerah perlu didorong terutama dalam ranah Dewan Perwakilan Rakyat Daerah (DPRD) dan leading sector di daerah. Alasannya di lembaga legislatif daerah penyusunan sebuah policy dimusyawarahkan DPRD bersama Pemerintah daerah dalam rumusan hukum yang berbentuk Perturan daerah (Perda).

Menurut data sampai dengan bulan September 2006 terdapat 5550 Perda yang disampaikan ke Departemen alam Negeri, dari jumlah tersebut terdapat 4088 perda yang layak untuk dilaksanakan, 201 perda dilakukan revisi, 1291 perda layak dibatalkan dan 42 perda masih dalam taraf evalusi. Saat ini sudah diterbitkan 600 Keputusan Menteri Dalam Negeri tentang Pembatalan Perda dan 619 perda masih dalam proses pembatalan ( Media Praja Depdagri, 2006).

Dari perspektif yuridis baik secara implisit maupun eksplisit landasan hukum untuk membuat green policy semakin menguat. Atas dorongan kesadaran yang semakin luas di seluruh dunia mengenai pentingnya upaya melindungi lingkungan hidup dari ancaman pencemaran dan perusakan, kebijakan lingkungan hidup

Yustisia Vol.1 No.1 Januari - April 2012 dituangkan dalam bentuk peraturan perundang-undangan secara resmi. Dengan demikian, timbul gelombang di seluruh dunia, yaitu gelombang legalisasi atau legislasi kebijakan lingkungan hidup. Setelah ditetapkannya begitu banyak peraturan-peraturan itu tidak efektif untuk mencegah terjadinya pencemaran dan perusakan lingkungan hidup. Penelitian yang dilakukan oleh Guningham dan Grabosky "there is not just one optimal instruments to reach environmental goals at the lowest cost. The strength and weaknesses of particular institutional features of a particular legal system may play a large role in that respect" (1998).

Pasal 28H ayat (1) dan Pasal 33 ayat (4) UUD 1945 dikatakan bahwa hak untuk memperoleh lingkungan hidup yang baik dan sehat serta pelayanan kesehatan yang baik, merupakan hak asasi manusia. Oleh karena itu, UUD 1945 jelas Sangat pro-lingkungan hidup, sehingga dapat disebut sebagai konstitusi hijau (green constitution).

Dengan demikian, segala kebijakan dan tindakan pemerintahan dan pembangunan haruslah tunduk kepada ketentuan mengenai hak asasi manusia atas lingkungan hidup yang baik dan sehat itu. Tidak boleh ada lagi kebijakan yang tertuang dalam bentuk undang-undang ataupun peraturan di bawah undang-undang yang bertentangan dengan ketentuan konstitusional yang pro-lingkungan ini. Apalagi, Indonesia sendiri merupakan satu negara kepulauan yang sangat rentan dan rawan bencana alam. Jika lingkungan hidup tidak dilindungi, pada saatnya

Green Constitution Sebagai... 136 
kerusakan alam yang terjadi justru akan merugikan bangsa Indonesia sendiri. Mulai dari ranah konstitusi UUD 1945, UU No. 32 Tahun 2009 tentang Perlindungan dan Pengelolaan Lingkungan mengatur dengan jelas betapa pentingnya filosofi nilai-nilai hijau mutlak diperlukan dalam legal drafting Undang-Undang termasuk Peraturan Daerah.

Sebagaimana diketahui bahwa Perda merupakan kebijakan daerah yang bersifat strategis yang memiliki kekuatan hukum tertinggi di daerah. Artinya apabila model formulasi legal drafting ini benar-benar mampu diterapkan maka diharapkan setiap Perda sebagai payung hukum di daerah yang dihasilkan tidak lagi merusak lingkungan sebagaima yang terjadi sekarang ini. Sebagaimana Perda yang mengatur lingkungan di beberapa daerah sudah mengaturnya seperti Surakarta, Sragen, Sukoharjo, Tangerang, Ngawi, Blora. Namun formulasi legal drafting seperti ini masih bersifat parsial, sedangkan yang lebih mendesak dibutuhkan formulasi legal drafting yang komprehensif, artinya tidak cukup menyusun Perda tentang lingkungan tetapi dalam setiap kali penyusunan Perda harus mempunyai nilai-nilai hijau/green seperti yang diamanatkan dalam UUD 1945 dan Pasal 14 UU No. 32 Tahun 2009 tentang Perlindungan dan Pengelolaan Lingkungan sehingga masing-masing Perda akan responsif terhadap lingkungan.

\section{Praktik-Praktik Tata Kelola Pemerintahan Yang Baik Di Daerah}

Yustisia Vol.1 No.1 Januari - April 2012

$$
\text { Menurut UNDP }
$$

"Governance" didefinisikan sebagai "pelaksanaan otoritas politik, ekonomi, dan administratif dalam pengelolaan sebuah negara, termasuk di dalamnya mekanisme yang kompleks serta proses yang terkait, lembaga-lembaga yang dapat menyuarakan kepentingan, baik perorangan maupun kelompok masyarakat dalam mendapatkan haknya dan melakukan tanggung jawabnya, serta menyelesaikan segala perselisihan yang muncul di antara mereka. Dikatakan lebih lanjut bahwa 'governance' berada dalam keadaan yang baik apabila terdapat pengelolaan sumber-sumber alam yang mempertimbangkan kepentingan sosial, lingkungan dan ekonomi secara selaras, serasi dan seimbang. Adapun ciri-ciri minimal sebagai prasyarat untuk mencapai 'good governance' adalah adanya transparansi, akuntabilitas, partisipasi, pemberdayaan hukum, efektifitas dan efisiensi, dan keadilan (UNDP, 1997). Good Governance menuntut pula komitmen terhadap pelaksanaan rule of law. Konsep rule of law paling tidak harus memenuhi karakter-karakter antara lain (a) supremasi hukum; (b) kepastian hukum; (c) hukum yang responsif; (d) penegakan hukum yang konsisten dan nondiskriminatif dan (e) keberadaan independensi peradilan. Lebih jauh Mas Ahmad Santosa menguraikan bahwa untuk memperkuat good governance di Indonesia paling tidak mensyaratkan halhal sebagai berikut:

1. Lembaga perwakilan yang mampu menjalankan fungsi kontrol yang efektif (effective representative system);

2. Pengadilan yang independen, mandiri, bersih, dan profesional;

Green Constitution Sebagai... 
3. Aparatur pemerintah (birokrasi) yang profesional dan memiliki integritas yang kokoh (strong, professional and reliable bureaucracy);

4. Masyarakat sipil yang kuat sehingga mampu melaksanakan fungsi kontrol publik (strong and participatory civil society); dan

5. Desentralisasi dan lembaga perwakilan di daerah yang kuat (democratic decentralization).

Penjelasan Pasal 53 ayat (2)

huruf b UU No. 9 Tahun 2004 menyebutkan bahwa yang dimaksud dengan Asas Umum Pemerintahan yang Baik adalah : asas kepastian hukum, tertib penyelenggaraan negara, keterbukaan, proporsionalitas, profesionalitas dan akuntabilitas sebagaimana dimaksud dalam UU No. 28 Tahun 1999 tentang Penyelenggaraan Negara Yang Bersih dan Bebas dari Korupsi, Kolusi dan Nepotisme. Berikut pengertian dari masing-masing asas tersebut menurut Pasal 13 UU No. 28 Tahun 1999 :

1. Asas Kepastian Hukum, yaitu asas dalam negara hukum yang mengutamakan landasan peraturan perundang-undangan, kepatuhan dan keadilan dalam setiap kebijakan penyelenggara negara.

2. Asas Tertib Penyelenggaraan Negara, yaitu asas yang menjadi landasan keteraturan, keserasian dan keseimbangan dalam pengendalian Penyelenggaraan Negara

3. Asas Keterbukaan, yaitu asas yang membuka diri terhadap hak masyarakat untuk memperoleh informasi yang benar, jujur dan tidak diskriminatif tentang penyelenggara negara dengan tetap memperhatikan perlindungan atas hak asasi pribadi, golongan dan rahasia negara

4. Asas Proporsionalitas, yaitu asas yang mengutamakan keseimbangan antara hak dan kewajiban Penyelenggara Negara

5. Asas Profesionalitas, yaitu asas yang mengutamakan keahlian yang berlandaskan kode etik dan ketentuan peraturan perundang-undangan yang berlaku

6. Asas Akuntabilitas, yaitu asas yang mengutamakan bahwa setiap kegiatan dan hasil akhir dari kegiatan Penyelenggara Negara harus dapat dipertanggungjawabkan kepada masyarakat atau rakyat sebagai pemegang kedaulatan tertinggi negara sesuai dengan ketentuan peraturan perundang-undangan yang berlaku.

Pemerintah yang bersih dan berwibawa dapat terwujud apabila pemerintah melaksanakan AAUPB sebagai pedoman bertindak. AAUPB merupakana prinsip hukum tak tertulis yang menjadi pedoman bertindak sekaligus menjadi tolok ukur untuk menguji keabsahan (rechtsmatigheid) perbuatan tata usaha negara dan untuk menguji segi kebijaksanaan / kemanfaatan (doelmatigheid) perbuatan tata usaha negara.

Peraturan Perundangundangan merupakan salah satu produk hukum, maka agar dapat mengikat secara umum dan memiliki efektivitas dalam hal pengenaan sanksi, dalam pembentukannya harus memperhatikan beberapa persyaratan yuridis. Persyaratan seperti inilah yang dapat dipergunakan sebagai landasan yuridis dari suatu Peraturan Perundang-undangan. Persyaratan yuridis yang dimaksud di sini adalah

Green Constitution Sebagai... 138 
1. Dibuat atau dibentuk oleh organ yang berwenang. Artinya suatu Peraturan Perundang-undangan harus dibuat oleh pejabat atau badan yang mempunyai wewenang untuk itu. Kalau persyaratan ini tidak diindahkan maka menjadikan suatu Peraturan Perundang-undangan itu batal demi hukum (van rechtswegenietig). Adanya kesesuaian bentuk/jenis Peraturan Perundang-undangan dengan materi muatan yang akan diatur. Ketidaksesuaian bentuk/jenis ini dapat menjadi alasan untuk membatalkan Peraturan Perundang-undangan yang dimaksud. Misalnya kalau di dalam Undang-Undang Dasar Negara Republik Indonesia Tahun 1945 menegasakan bahwa suatu ketentuan akan dilaksanakan dengan UndangUndang, maka hanya dalam bentuk Undang-Undang-lah itu harus diatur.

2. Adanya prosedur dan atata cara pembentukan yang telah ditentukan. Pembentukan suatu Peraturan Perundang-undangan harus melalui prosedur dan tata cara yang telah ditentukan. Misalnya suatu Rancangan Undang-Undang dibahas oleh Dewan Perwakilan Rakyat dan Presiden untuk mendapat persetujuan bersama, Peraturan Daerah ditetapkan oleh Kepala Daerah setelah mendapat persetujuan bersama Dewan Perwakilan Rakyat Daerah. Dalam rangka pengundangannya juga harus ditentukan tata caranya, misalnya UndangUndang diundangkan dalam

Yustisia Vol.1 No.1 Januari - April 2012
Lembaran Negara, agar mempunyai kekuatan mengikat.

3. Tidak boleh bertentangan dengan Peraturan Perundang-undangan yang lebih tinggi tingkatannya. Sesuai dengan pandangan stufenbau theory, Peraturan Perundang-undangan mengandung norma-norma hukum yang sifatnya hirarkhis. Artinya suatu Peraturan Perundang-undangan yang lebih tinggi tingkatannya merupakan grundnorm (norma dasar) bagi Peraturan Perundang-undangan yang lebih rendah tingkatannya. Oleh sebab itu Peraturan Perundang-undangan yang lebih rendah tingkatannya tidak boleh melanggar kaidah hukum yang terdapat di dalam Perauran Perundang-undangan yang lebih tinggi tingkatannya.

Selain landasan filosofis, sosiologis dan yuridis masih terdapat landasan lain, yaitu landasan teknik perancangan. Landasan yang terakhir ini tidak boleh diabaikan dalam membuat Peraturan Perundang-undangan yang baik karena berkaitan erat dengan hal-hal yang menyangkut kejelasan perumusan, konsistensi dalam mempergunakan peristilahan atau sistematika dan penggunaan bahasa yang jelas. Penggunaan landasan ini diarahkan kepada kemampuan person atau lembaga dalam merepresentasikan tuntutan dan dukungan ke dalam produk hukum yang tertulis, yakni Peraturan Perundang-undangan.

Dalam penyusunan produk produk hukum daerah sebaiknyadisertai Naskah Akademik. Naskah Akademik merupakan

Green Constitution Sebagai... 139 
Rancangan Pendahuluan untuk menyusun Draft Raperda dan merupakan hasil kesimpulan dari pekerjaan tim peneliti. Dapat dikatakan bahwa suatu Naskah Akademik sebagai kesimpulan dari laporan penelitian yang telah dilakukan beberapa lama dengan metode tertentu. Idealnya sebuah Laporan Penelitian haruslah memenuhi kaidah-kaidah tata tulis yang telah ditentukan. Dalam penyusunan Perda idealnya didahului dengan Naskah Akademik. Hasil penelitian di tiga lokasi penelitian ternyata tidak semua Perda didahului dengan Naskah Akademik. Untuk Perda Pegelolaan Lingkungan Hidup sudah didahului dengan Naskah Akademik, namun tidak semua Perda didahului dengan Naskah Akademik. Penyusunan Naskah Akademik ini mengacu pada UU No. 12 Tahun 2011 tentang Pembentukan Peraturan PerundangUndangan. Bahwa Naskah Akademik merupakan bagian yang tidak dapat dipisahkan dari penyusunan sebuah Rancangan Undang-Undang termasuk Perda karena dimuat gagasan-gagasan pengaturan serta materi muatan perundang-undangan bidang tertentu yang telah ditinjau secara sistematik holistik dan futuristik dari berbagai aspek ilmu. Naskah Akademik adalah Naskah awal yang memuat gagasangagasan pengaturan dan materi muatan perundang-undangan bidang tertentu. Naskah Akademik memuat gagasan pengaturan suatu materi perundangundangan (materi hukum) bidang tertentu yang telah ditinjau secara-holistik-futuristik dan dari berbagai aspek ilmu, dilengkapi dengan referensi yang memuat : urgensi, konsepsi, landasan, alas hukum dan prinsipprinsip yang digunakan serta pemikiran tentang norma-norma yang telah dituangkan ke dalam bentuk uraian yang sistematis dan dapat dipertanggungjawabkan secara Ilmu Hukum dan sesuai dengan politik hukum yang telah digariskan.

Yustisia Vol.1 No.1 Januari - April 2012
Unsur-unsur yang perlu ada dalam suatu Naskah akademik adalah urgensi disusunnya pengaturan baru suatu materi hukum yang menggambarkan :

1. Hasil inventarisasi hukum positif;

2. Hasil inventarisasi permasalahan hukum yang dihadapi;

3. Gagasan-gagasan tentang materi hukum yamg akan dituangkan ke dalam Rancangan Perda;

4. Konsepsi landasan, alas hukum dan prinsip yang akan digunakan;

5. Pemikiran tentang norma-normanya yang telah dituangkan ke dalam bentuk pasal-pasal;

6. Gagasan awal naskah Rancangan Perda yang disusun secara sistematis : bab demi bab, serta pasal demi pasal untuk memudahkan dan mempercepat penggarapan Raperda selanjutnya oleh instansi yang berwenang menyusun Raperda tersebut.

\section{Pertimbangan lain perlunya partisipasi masyarakat dalam penyelenggaraan pemerintahan adalah:}

1. bahwa keterlibatan masyarakat merupakan unsur penting dalam membangun dan mengembangkan system pemerintahan yang aspiratif dan demokratis, mampu melayani kepentingan dan kebutuhan masyarakat dengan baik;

2. partisipasi sebagai salah satu prinsip pemerintahan yang baik (good governance) perlu dikembangkan dalam rangka mendorong warga masyarakat menggunakan pikiran dan pendapatnya dalam setiap pengambilan keputusan yang menyangkut kepentingannya,

Green Constitution Sebagai... 140 
pelaksanaan dan evaluasi penyelenggaraan pemerintahan dan program pembangunan di daerahnya;

3. pelibatan masyarakat baik secara langsung maupun tidak langsung akan membangun kemitraan antara pemerintah dan masyarakat untuk bersama-sama bertanggungjawab terhadap keberhasilan penyelenggaraan pemerintahan dan pembangunan.

\section{E. Penutup}

Dalam kondisi saat ini, dimana ancaman krisis daya dukung ekosistem dan lingkungan hidup yang dihadapi Indonesia sangat nyata, maka legislasi norma hukum lingkungan di tingkat daerah baik kota, kabupaten dan provinsi sangat diperlukan seiring dengan ikhtiar di tingkat nasional maupun dunia internasional untuk memperkuat demokrasi dan negara hukum, serta tata kelola pemerintahan yang baik (good governance). Karena legalisasi lingkungan hidup dianggap tidak cukup, maka perlu ditingkatkan penormaan lingkungan hidup pada level konstitusi Negara. Konstitusionalisasi lingkungan hidup dalam konstitusi suatu Negara dianggap penting bukan saja karena konstitusi tidak mudah dirubah, tapi juga karena konstitusi merupakan supreme law of the land yang menjadi tujuan, pedoman dan alat ukur kehidupan berbangsa dan bernegara. Oleh karena Konstitusionalisasi lingkungan hidup dalam konstitusi Indonesia sendiri sudah dilakukan dalam amandemen UUD 1945, Konstitusionalisasi lingkungan hidup dalam konstitusi Indonesia sendiri sudah dilakukan dalam amandemen UUD 1945, namun tidak banyak pihak

Yustisia Vol.1 No.1 Januari - April 2012 yang memperhatikan hal ini secara serius. Pasal $28 \mathrm{H}$ ayat (1) dan Pasal 33 ayat (4) UUD 1945 merupakan bukti bahwa konstitusi Indonesia adalah Konstitusi Hijau (Green Constitution) yaitu dalam Pasal $28 \mathrm{H}$ ayat (1) dan Pasal 33 ayat (4) UUD 1945 yang merupakan bukti bahwa konstitusi Indonesia adalah Konstitusi Hijau (Green Constitution) maka idealnya Pemerintah dan DPR serta Pemerintah Daerah dalam hal ini Eksekutif dan DPRD memegang peranan penting dan startegis dalam menghasilkan Peraturan yang pro terhadap lingkungan, tidak tumpang tindih dan harmoni antar peraturan yang satu dengan peraturan perundang-undangan diatasnya. Dalam kenyataanya di daerah terdapat banyak peraturan daerah yang tidak harmonis dan tumpang tindih bahkan justru tidak melindungi fungsi lingkungan hidup (tidak berbasis pada green legislation). Bahkan banyak perda yang dibatalkan dan bertentangan dengan UndangUndang. Hal ini dikarenakan minimnya pengetahuan dan pemahaman aparatur pemerintah daerah dan DPRD tentang legal drafting produk hukum daerah, budaya copy paste perda daerah lain, dan keterbatasan anggaran. Di sisi lain, selain istilah ini termasuk baru, pemahaman dan kepekaan aparatur sendiri tentang green legislation sangat terbatas, prosedur penyusunan peraturan daerah yang tidak responsif terhadap pentingnya fungsi lingkungan di masa yang akan datang. Hal yang sangat penting adalah bahwa kondisi satu daerah dengan daerah lain berbeda sehingga akan sangat berpengaruh pada produk hukum yang dihasilkan nantinya, apakah sudah good norm dan good process serta sesuai dengan kondisi daerahnya. Oleh karena itu diperlukan formulasi untuk membangun dan 
menciptakan Peraturan Daerah agar berbasis pada green legislation dan tercipta praktik-praktik tata kelola pemerintahan yang baik. Tujuan jangka panjang penelitian ini adalah merumuskan model kebijakan formulasi legal drafting Peraturan Daerah (Perda) berbasis Green Legislation dalam rangka pengembangan praktik-praktik tata kelola pemerintahan yang baik di daerah melalui penguatan peran eksekutif (leading sector seperti bagian hukum, badan lingkungan hidup, Pusat Regional Jawa Kementrian LH) dan pimpinan serta anggota DPRD melalui strategi, mekanisme, dan pemberdayaan potensi, serta perbaikan prosedur penyusunan peraturan daerah agar memperhatikan pelestarian fungsi lingkungan hidup. Target khusus yang ingin dicapai adalah optimalisasi pemerintah daerah dan DPRD dalam rangka memformulasikan dan selanjutnya menghasilkan perda yang berbasis pada green legislation. Harapannya adalah Perda yang dihasilkan good norm dan good process serta green sehingga sesuai dengan UUD 1945. 


\section{DAFTAR PUSTAKA}

Abdurrahman, 1990. Pengantar Hukum Lingkungan Indonesia, Alumni, Bandung.

Bartleet A G, MC Nurse, R B Chetri dan S Khaerel 1993 Towards Effective Community Forestry Through Forest User Groups. Journal of World Forest Management 7 (1), p. 49-69.

Bhatt C. P. 1990. The Chipko Andolan: Forest Conservation Based on People's Power. Environment and Unrbanization Journal 2(1), p. 7-18.

Brown, Lester E., Christopher Flavin, Sandra Postel, 1994. Menyelamatkan Planet Bumi: Bagaimana Membentuk Sebuah Ekonomi Global yang Berkesinambungan dari Segi Lingkungan Hidup, Terjemahan Hermoyo, Yayasan Obor Indonesia, Jakarta.

Esty, .C. and Porter, M. 2005. National Environmental Performance: An Empirical Analysis of Policy Results and Determinants. Environmental and Development Economics Journal. Vol. 10, p. 391-434.

Gunningham, N. and Grabosky, P. 1998. Smart Regulation, Designing Environmental Policy, Oxford, Clarendon Press.

I Gusti Ayu. 2005. Judicial Review Undang-Undang Nomor 7 Tahun 2004 Tentang Sumber Daya Air. Laporan Penelitian MKRI. Fakultas Hukum UNS : Surakarta.

. 2006. Urgensi Pengelolaan SDA Pasca Putusan MKRI 2005. Laporan Penelitian MKRI. Fakultas Hukum UNS : Surakarta.

. 2007 .Sinkronisai Perda Kota Surakarta No. 2 tahun 2006 tentang Pengendalian LH Terhadap UUPLH Laporan Penelitian DIPA FH UNS. Fakultas Hukum UNS : Surakarta.

. 2007. Urgensi Evaluasi Kelembagaan PDAM Kota Surakarta Laporan Penelitian PDAM-FH UNS. Fakultas Hukum UNS : Surakarta.

. 2007. Harmonisasi Perda dengan peraturan perundang-undangan di bidang ekonomi yang berperspektif Gender Laporan Penelitian Kementerian PP RI. Fakultas Hukum UNS : Surakarta.

. 2008. Identifikasi Capaian Program RAN HAM Kota Surakarta Laporan Penelitian P3KHAM UNS. LPPM UNS Surakarta.

Yustisia Vol.1 No.1 Januari - April 2012

Green Constitution Sebagai... 143 
. Model Formulasi Legal Drafting Berbasis Green Legislation Dalam Rangka Pengembangan Praktik-Praktik Tata Kelola Pemerintahan Yang Baik Di Daerah, Laporan Penelitian Hibah Kompetensi Tahun I, Fakultas Hukum UNS Surakarta.

Jimly Asshiddiqie. 2009. Green Constitution. Jakarta: Rajagrafindo Persada.

Koesnadi Hardjasoemantri. 2005. Hukum Tata Lingkungan 2005. Yogyakarta: Gadjah Mada University Press

Lawrence M. Friedman, 1997. The Legal System : A Social Science Perspective. Russel Sage Foundation: New York.

Leenen, H.J.J. Milieuhygienerecht, 2e druk, Amson, Alphen aan Rijn. 1971.

Lexy J. Moleong. 2005. Metodologi Penelitian Kualitatif. Bandung: P.T. Remaja Rosdakarya.

Marzuki. 2002. Metodologi Riset. Yogyakarta: BPFE-UII.

Peter Mahmud Marzuki. 2006. Penelitian Hukum. Akarta: Kencana Prenada Media Group.

Michael G. Faure and Jason S. Johnston. 2009. The Law and Economics of Environmental Federalism: Europe and the United States Compared, Virginia Environmental Law Journal. Vol 27, p. 244-246.

Emil Salim. 1991. Pembangunan Berwawasan Lingkungan. Jakarta: LP3ES

Siahaan, N.H.T., 1989. Ekologi Pembangunan, dan Hukum Tata Lingkungan, Erlangga, Jakarta.

Steinzor, R.I. 1998. Reinventing Environmental Regulation: The Dangerous Journey From Command to Self-Control. Harvard Law Review. Vol. 22, p 103-202.

Peraturan Perundang-Undangan:

UUD 1945

UU No. 28 Tahun 1999 tentang Penyelenggaraan Negara Yang Bersih dan Bebas dari Korupsi, Kolusi dan Nepotisme 